\title{
Subsidence management and 3D analysis at Ukwa underground manganese mine of MOIL Limited
}

\author{
GG Manekar, D Shome and MP Chaudhari \\ MOIL Limited \\ Nagpur, India \\ ggmanekar61@gmail.com
}

\begin{abstract}
Subsidence is a universal process that occurs in response to the voids created by extracting solids or liquids from beneath the Earth surface. The void created by the underground extraction causes significant changes in the magnitude and orientation of the insitu stress field and results in deformations both in the stope and in the surrounding rocks. Deformations in the underground workings eventually reach the ground surface and may form subsidence depressions, open fractures, pits, and troughs. In this context, MOIL has conducted in-house research investigations of the subsidence phenomenon related to the underground mining of manganese ore at Ukwa mine. Considering the ore body and the hanging wall characteristics the subsidence phenomenon would be very much comparable to a coal mine situation. Taking this factor into consideration, the prediction of subsidence parameters has been carried out by adopting the well accepted and conventional coal mining subsidence prediction methods that have been developed in the country and are suitable for Indian mining conditions. The computations showed that the parameters of importance are well within the limit for permissible subsidence in general as well as for forest land. The monitoring is done on a continuous basis at quarterly intervals, at two sites in the forest land above the mine workings at Ukwa Mine. The quarterly monitoring data from October 2014 to March 2016 for both the locations clearly suggests that no noticeable movement took place in any of the three orthogonal directions at these places. This is evidence enough that the subsidence at the Ukwa mine surface land is not of any measurable significance. The paper presents the scientific investigations carried out by the MOIL for prediction of subsidence parameters and successful 3-D analysis of subsidence monitoring at Ukwa Mine.
\end{abstract}

Keywords-Deformation; Manganese; Monitoring; Numerical Modeling; Subsidence.

\section{INTRODUCTION}

The Ukwa Mine of MOIL Limited is being worked since 1903. The total lease hold area of the mine is 322.6083 ha, which includes three (3) leases in Ukwa, Lugma, Gudma and Samnapur villages in Tahsil Paraswada, Distt. Balaghat of Madhya Pradesh. Composite Lease Plan of 3 Leases of Ukwa Mine with forest area of lease II (73.567 ha) is shown in (Fig.1).

\section{A. Location and Accessibility}

Ukwa mine is located in Paraswada Tahsil of Balaghat District, Madhya Pradesh and falls in Survey of India toposheet No. $64 \mathrm{C} / 5$. The mine takes the name of a nearby village, Ukwa. Ukwa is located on Balaghat - Paraswada, all weather, State Highway No. 26 road $45 \mathrm{kms}$ from Balaghat town.

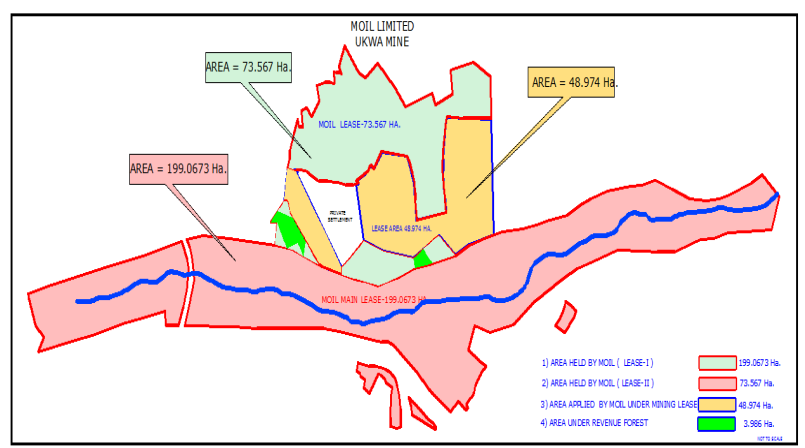

Fig. 1. Composite plan of 3 (Three) leases of ukwa mine

At $42 \mathrm{~km}$ stone, the Balaghat-Paraswada road almost touches South Western part of the Manganese deposit of Ukwa. Paraswada (Baihar) is $20 \mathrm{~km}$ further ahead. Balaghat is connected by all weather roads to important places like Nagpur, Gondia, Raipur etc. The nearest rail head for the mine is Balaghat.

The manganese ore produced in this mine from underground is being dispatched by trucks to various Silico and Ferro manganese industries and steel plants in the country.

\section{GeOteChNiCAL Details}

In the subsidence process, strains induced by mining and transmitted through intervening strata to the surface may be compressive or tensile and may have both horizontal and vertical components. Considering the facts, geotechnical studies has been carried out at the mine for prediction of subsidence parameters.

The ore zone of Ukwa is associated with Munsar formation of Saucer group. The ore zone strikes almost in 
$\mathrm{N}-\mathrm{S}$ direction and dip with low angle due west $\left(15^{\circ}\right.$ to $\left.45^{\circ}\right)$. Mica schist of Munsar formation constitutes the hang wall, whereas the quartz mica schist and gritty quartzite constitute the foot wall of the deposit. The mineralization is associated with low metamorphic grade. The deposit is linear and do not show any structural disturbances such as fold/ faults. Owing to regular linear disposition of ore bed within mica schist of Munsar formation, it is categorized as stratified. The thickness various from $2 \mathrm{~m}$ to $4.5 \mathrm{~m}$, which increases with depth indicate the probable development of synclinal trough on west of the deposit.

The phyllites are underlain by the manganese ore horizon, comprising alternating bands of manganese ore and magniferous charity-jespery quartzite, quartzite with extremely rare intercalations of schistose rocks. The ore horizon is exposed over a strike length of about $5 \mathrm{~km}$. it is rather difficult to ascertain the thickness of the ore horizon on the surface, as either or both of its contacts are covered by mine dumps. The drilling data indicate that the ore horizon ranges in thickness between $0.27 \mathrm{~m}$ and $6.10 \mathrm{~m}$ with an average thickness of $3.03 \mathrm{~m}$. The graphic lithology of a borehole of Ukwa mine is shown in (Fig. 2).

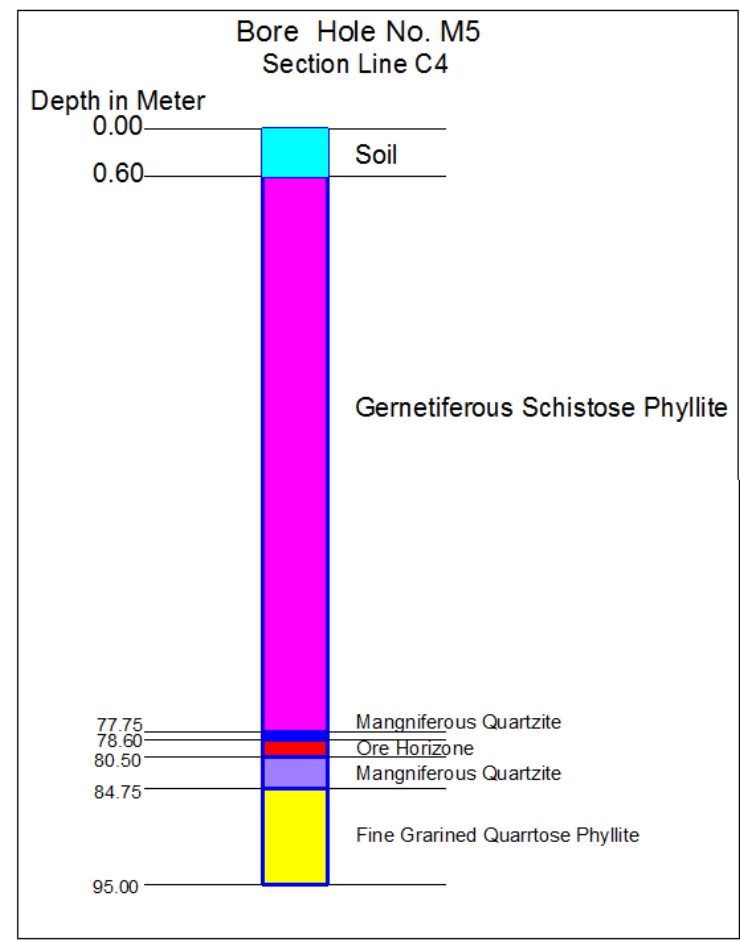

Fig. 2. The graphic lithology of a borehole of Ukwa mine

The inter-banding of the ore and quartzite is a characteristic feature of the Ukwa deposit. The close and regular nature of the bands simulates the banded hematite/ magnetite quartzite. The thickness of the ore and quartzite bands varies from less than $0.5 \mathrm{~cm}$ to as $0.5 \mathrm{~m}$. The ore horizon consists of three units, based on the manganese content, the bottom unit comprising quartzite with thin streaks of manganese ore, the middle unit comprising alternating bands of manganese ore and the cherty-Jaspery quartzite and the top unit in composition similar to that of the bottom unit. The middle unit, which forms the main source of manganese ore termed as ore bed. Banding in the ore horizon representing bedding strike $\mathrm{N} 30^{\circ}$ to $85^{\circ}-\mathrm{S} 30^{\circ}$ to $65^{\circ}$ and dips at $20^{\circ}$ to $45^{\circ}$ towards northwest and is parallel to the foliation of the enclosing schistose rocks. Fig. 3 represents the behaviors of ore body up to the depth of 200 $\mathrm{m}$ below 1450 'L at Ukwa Mine.

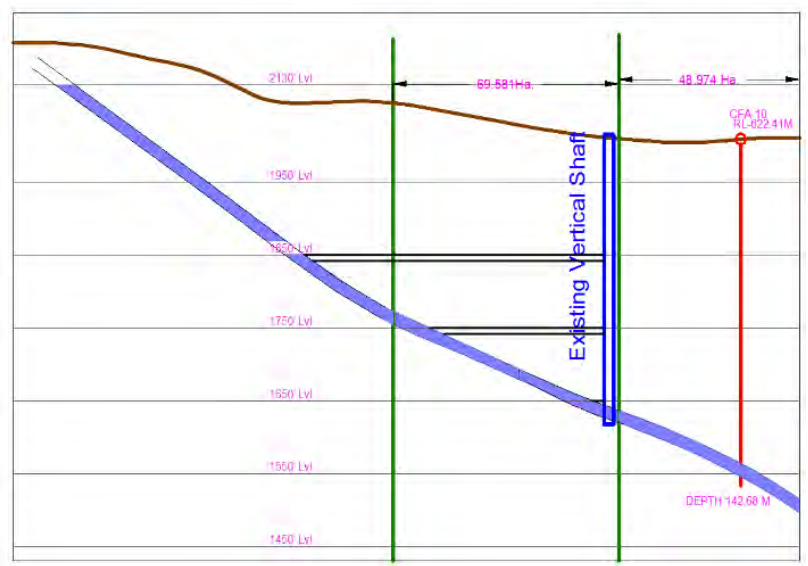

Fig. 3. Location of vertical shaft and proposed $2^{\text {nd }}$ vertical shaft and behavior of ore body

\section{A. Ore Body}

The ore horizon being more competent than the enclosing rocks (immediate hanging wall and foot wall) has developed closely spaced orthogonal joints viz. dip (J1), strike $(\mathrm{J} 2)$, and oblique $(\mathrm{J} 3)$ joint sets, resulting in fragmentation of the ore material. The ore body breaks into thin rectangular slabs. It is because of closely spaced joints and the tendency of the ore horizon of easy splitting along the bedding the ore, i.e. along $\mathrm{J} 1$. The ore body on hanging wall (HW) side is associated with in extremely soft and loose, fine grained clay and phyllitic rocks. The average thickness of roof layer varies from $1 \mathrm{~cm}$ to $10 \mathrm{~cm}$ and the mean orientations of the layers are mostly parallel as shown in (Fig. 4 (a)). On the Foot Wall (FW) side, the ore body is more competent than that of the HW side as shown in (Fig. 4 (b)). The joints are tight and their spacing varies from 15 to $30 \mathrm{~cm}$. [5].

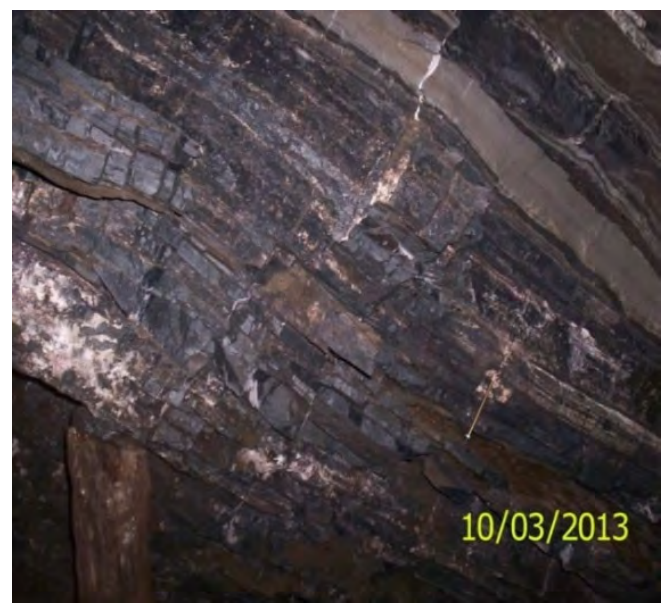


Fig. 4 (a). Ore body on HW side showing joint sets J1- bedding plane and $\mathrm{J} 2$ - normal to the bedding plane, and a clay band

\section{B. Foot wall and Hang wall Rocks}

The immediate foot wall (FW) and hanging wall (HW) rocks of the ore horizon show a higher incidence of feldspar in the rocks. In contrast to the fine grained phyllitic rocks at the footwall of the ore horizon, the hanging wall rocks are coarse grained mica schist.

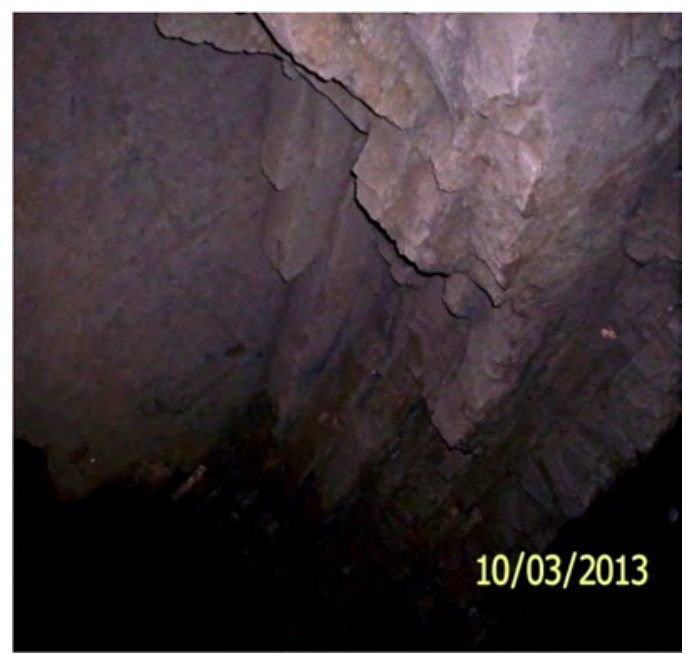

Fig.4 (b). Ore body on FW side showing joint sets; J1-bedding plane, J2 normal to the bedding plane, J3- vertical striking along the dip

The foot wall rocks are highly foliated and the foliation is tight. The immediate HW rock, about $3 \mathrm{~m}$ from the ore contact, is highly foliated. Further on footwall side, several joint sets are found. The spacing for all the joint sets varies from $20 \mathrm{~cm}$ to $30 \mathrm{~cm}$. All the joints are tight. Some smooth joints are also identified. The joints are filled with altered calcite mineral and they are tight also. The steronet plot of poles of joint sets on FW side has been carried out. A set of dip and dip direction measurements is most conveniently plotted as poles on a streonet, in which each plane is represented by a single point. A typical plot of poles indicates the orientation of a large number of discontinuities shown in (Fig. 5 (a) and (b)).

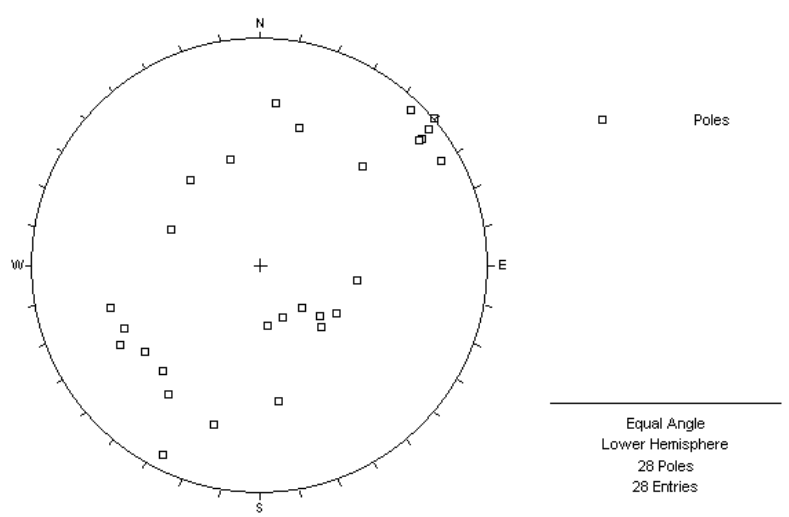

Fig. 5(a). Stereonet plot of poles of joints in the ore body
There are three joint sets in rock on the HW side. The spacing of the joint in a set varies from 25 to $60 \mathrm{~cm}$. A typical plot of contour of poles shows that there are mainly two sets of joints, both dipping in the same direction, i.e. along dip of the ore body.
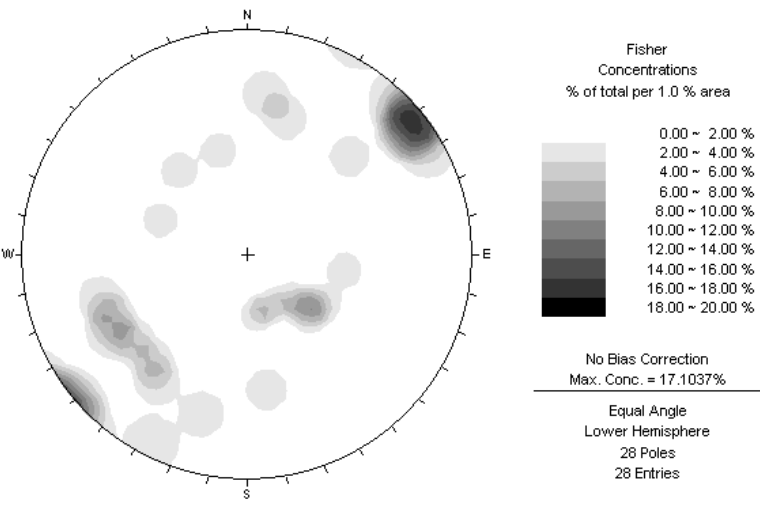

Fig.5 (b). Contours showing concentration of poles of joint sets

\section{MODIFICATION IN UNDER GROUND DEVELOPMENT AND STOPING}

The developments for stope preparation at 1950 'L, 1850 'L has been carried out in the manganese ore body. The HW and the FW contacts are weak and the ore body is highly jointed. A brief description of the method of stoping at 1950 ' $\mathrm{L}$ and $1850^{\prime} \mathrm{L}$ of Ukwa mine is as below;

Three sublevels are developed between two levels in the stope. At each sublevel, tracks are laid for hauling the ore produced in the stope to the production incline. The ore between two sublevels are extracted sequentially into three slices of cut and fill. River sand is hydraulically transported for filling into the stope. The slices are extracted by driving a drift of size $2.5 \times 2.1 \mathrm{~m}$ to the boundary of the stope. From one end of the drift, it is widened, heightened and filled in stretches of $5 \mathrm{~m}$. The blasted ore is loaded manually in a mine car standing on the track laid at the sublevel. Due to limited exposure of the back and the HW over a stretch of 5 $\mathrm{m}$, and support of the stope back by rock bolts and props, major ground control problems have not been observed in stopes. The only limitation is slow production due to manual handling of blasted ore in the stope. Further, a junction is formed where the track at sublevels crosses the production incline. At each such junction, a turn table is laid for transferring the mine tub from the sub-level to the incline. This system makes the hoisting operation very slow.

To overcome this slow productive method of stoping, vertical shaft has been sunk and method of stoping has been modified for lower level beyond 1750'L. Method of stoping at $1750^{\prime} \mathrm{L}$ to $1850^{\prime} \mathrm{L}$ is room and pillar mining and approached by vertical shaft. Vertical level interval is $30 \mathrm{~m}$. Haulage road, cross cut are developed in footwall side. The run of mine and waste rock is transported to surface by vertical shaft through u-tubs. Post filling is being done by hydraulic sand stowing. For support roof bolts and cable bolts has been used as pre-mining support system and crown pillar of $8 \mathrm{~m}$ is being left for stability of the upper level. 
For prediction of subsidence for metal mine two dimensional numerical modeling techniques has been deployed to estimate the stress and displacement on the ground surface and around the stope and rib pillar [8]. For stability analysis of the underground structures of Ukwa Mine, numerical modeling has been carried out to estimate the stress and displacement distribution around the stope during entire stoping operations.

\section{A. Numerical Modeling of the underground stopes by FEM}

The numerical modeling of stopes was conducted by FEM using Strand 7 FEM software.

Input data used in FE model of stopes;

1. The ore body
a. $\quad$ Thickness $=4.5 \mathrm{~m}$
b. $\operatorname{Dip}=45^{\circ}$
c. Elastic modulus $=3 \mathrm{GPa}$
d. Poisson's Ratio $=0.25$

2. The sand in stopes filled by hydraulic stowing
a. Compressive modulus $=200 \mathrm{MPa}$
b. Poisson's Ratio $=0.1$

3. The HW and FW rocks
a. Elastic modulus $=15 \mathrm{GPa}$
b. Poisson's Ratio $=0.2$

4. The soft clay of HW contact
a. $\quad$ Elastic modulus $=500 \mathrm{MPa}$
b. Poisson's Ratio $=0.1$
c. Thickness $=1 \mathrm{~m}$

5. In-situ stress $=$ Gravity Loading

\section{B. Result of the modeling}

Maximum principal stresses around the stope back normal to HW and principal stress directions around stope back has been modeled for various mining lifts for analysis of ground movement and support design. It is shown in (Fig. 6 and 7).

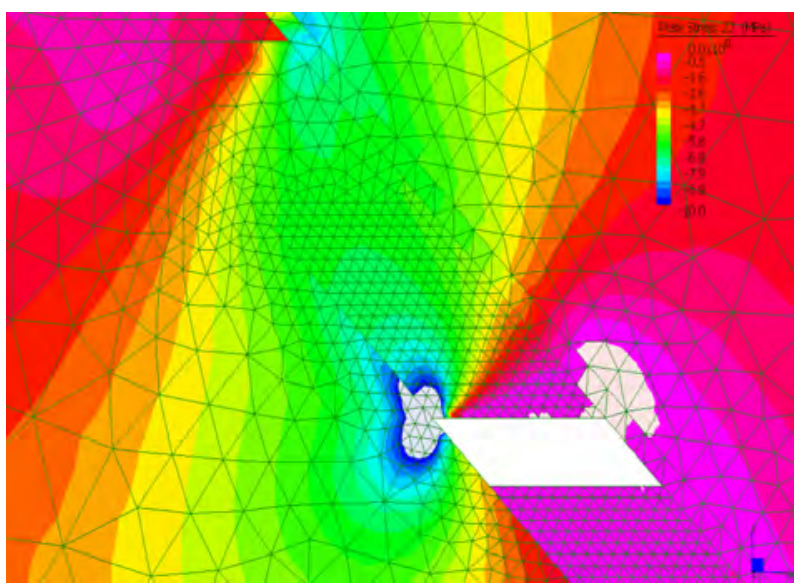

Fig. 6. Maximum principal stresses around the stope back normal to HW, 1750’L, Slice no. 7

No failure of the roof back is noticed during modeling at middle of the stope and at upper side of the stope.
Moreover, to increase the safety of failure zone, roof bolts has been used for stability of the roof back. Moreover, stopes have been filled by hydraulic sand stowing after mining.

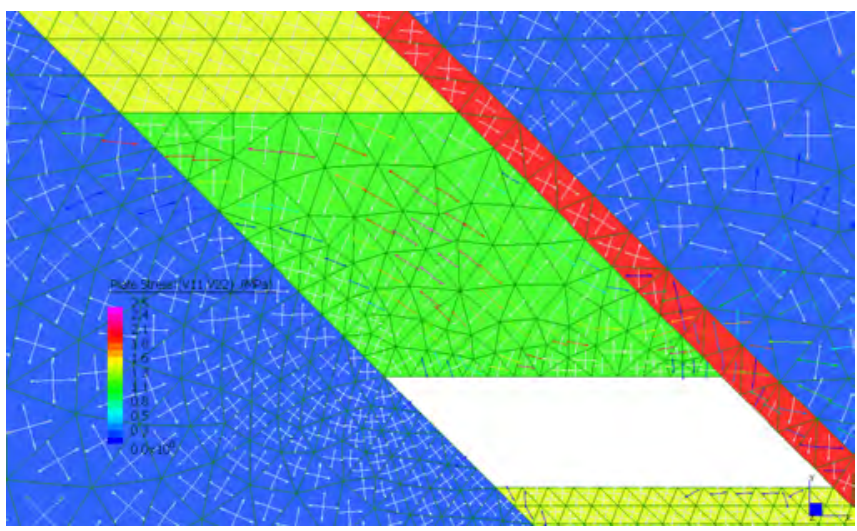

Fig.7.The principal stress directions around stope back, 1750’ L, Slice no. 9

\section{ESTIMATION OF SUbSIDENCE PARAMETRES}

The rock mass rating (RMR) of the hang wall is 30 , footwall - 40 and ore body is 55, average RMR is 50 of Ukwa Mine at 1750 'L [1]. Considering the values of strength and RMR, the hangwall rocks are comparable with the softer version of coal measure rocks. Since subsidence observations in India as well as other parts of the world are predominantly related to coal mining areas, subsidence predication is calculated on the basis of coal mining experience in the country and abroad.[4].

The following subsidence terms used in this scientific report is defined as;

- Non-effective width of extraction (NEW): This is the maximum width of an excavation upto which no subsidence on the surface takes place.

- Critical width of extraction (CW): This is the width of an excavation at which the subsidence attains its maximum value. Any further increase in the extraction width beyond this value does not increase the subsidence. The critical width in India is about 3.5 times NEW. Any width of extraction less than the critical width but greater than NEW is the sub-critical width of extraction (SW).

- Maximum possible subsidence $\left(\mathrm{S}_{\max }\right)$ : This is the value of subsidence, which takes place at the critical width of extraction and beyond.

- Subsidence Factor $\left(\mathrm{S}_{\mathrm{F}}\right)$ : This is the ratio of the $\mathrm{S}_{\max }$ and the extraction thickness.

The following data have been used for subsidence calculation of Ukwa mine:

Depth of the middle of the stope from the surface, $\mathrm{H}=67.50 \mathrm{~m}$ up to $1750^{\prime} \mathrm{L}$

Inclined stope height (extraction width for the purpose of subsidence calculation $\mathrm{W}=30 / \operatorname{Sin} 45^{\circ}=42.42 \mathrm{~m}$ 
Maximum extraction thickness, $\mathrm{M}=4.5 \mathrm{~m}$

Width to depth ratio, $\mathrm{W} / \mathrm{H}=42.42 / 67.50=0.628$

Since the method of stoping is horizontal cut and fill, the observations over stowed panels are used. The subsidence factor $\left(\mathrm{S}_{\mathrm{F}}\right)$ for well-stowed panels in India ranges between 0.02 and 0.05 , and the value of ratio $\mathrm{NEW} / \mathrm{H}$ in India ranges between 0.3 and 0.8 , the lower bound values occurring in softer strata. Therefore, in the case of Ukwa mine NEW/H value as 0.3 has been considered. The $\mathrm{W} / \mathrm{H}$ ratio at Ukwa Mine is found to be 0.628 , which is much less than the $\mathrm{CW} / \mathrm{H}(2.198)$ and as such is sub-critical. Because of the gradient of the ore body, the filling of the stope is expected to be very tight and therefore the lower value of the subsidence factor may safely be taken for prediction calculation. Further as the panel is sub-critical, the maximum subsidence $(\mathrm{S})$ that may be anticipated will be:

$$
\mathrm{S}=0.01 \mathrm{M}=0.01 \times 4.5=45 \mathrm{~mm}
$$

The value of $\mathrm{S}(45 \mathrm{~mm})$ is to be substituted in the following relations:

$$
\begin{aligned}
& \text { Maximum slope of subsidence }(\mathrm{G})= \\
& 2.0 \mathrm{~S} / \mathrm{H}=2.0(45 / 67.50)=1.33 \mathrm{~mm} / \mathrm{m} \\
& \text { Maximum compressive strain }\left(\mathrm{E}^{-}\right)= \\
& 1.1 \mathrm{~S} / \mathrm{H}=1.1(45 / 67.50)=0.73 \mathrm{~mm} / \mathrm{m} \\
& \text { Maximum tensile strain }\left(\mathrm{E}_{+}\right)= \\
& 1.0 \mathrm{~S} / \mathrm{H}=1.0(45 / 67.50)=0.66 \mathrm{~mm} / \mathrm{m}
\end{aligned}
$$

TABLE 1. SAFE LIMITS OF SUBSIDENCE FOR VARIOUS PROPERTIES IN INDIA [3]

\begin{tabular}{|l|l|l|l|}
\hline \multicolumn{1}{|c|}{$\begin{array}{c}\text { Type of } \\
\text { property }\end{array}$} & $\begin{array}{c}\text { Safe tensile } \\
\text { strain }\end{array}$ & Slope & Elongation \\
\hline Railway line & $3 \mathrm{~mm} / \mathrm{m}$ & $10 \mathrm{~mm} / \mathrm{m}$ & - \\
\hline Water bodies & $4.5 \mathrm{~mm} / \mathrm{m}$ & - & - \\
\hline Building & - & - & $60 \mathrm{~mm}$ \\
\hline Aerial ropeway & $3 \mathrm{~mm} / \mathrm{m}$ & - & - \\
\hline Forest land & $20 \mathrm{~mm} / \mathrm{m}$ & - & - \\
\hline
\end{tabular}

The safe tensile strain predicted by Saxena and Singh is 20 $\mathrm{mm} / \mathrm{m}$ for forest land. The predicted tensile strength at Ukwa mine is $0.66 \mathrm{~mm} / \mathrm{m}$, which is much less than the safe limit at Ukwa Mine.

\section{OVERVIEW OF SUBSIDENCE}

Predictions for subsidence parameters have been estimated by geotechnical and numerical modeling studies. To start the 3-D monitoring some of the best suited examples for underground mining has been referred. Gist of the referred literature for subsidence [6], is as below;

- Kerridge(1952) has reported the effects of cavernous limestone underlying coal seams in the Cherapunji Coalfield of Assam. Swallow-holes (probably crownholes) were observed on the surface indicating that such subsidence holes penetrated through the coal seams. Special problems occurred in assessing the reserves of coal and also in safely working the coal seams in view of the presence of a risk of possible collapse into cavities beneath the coal seams. Such underlying cavities in the limestone were made more hazardous due to the general area being within an earthquake belt, and there were records of accidents involving subsidence of underground working into such cavities during periods of earth tremors.

- Kumar et al (1973) refer to subsidence observation in the Jaria, Raniganj, Karanpura and Korba coalfields where results have been obtained at mines in the depth range of 68 to $165 \mathrm{~m}$.

- The subsidence results of Kumar et al were obtained at eleven mines and they report that no subsidence was observed in two cases where room and pillar working was practiced.

- Hunt (1980) reported observations on subsidence holes and troughs and found that both these forms occurred together in the depth range of $23-50 \mathrm{~m}$. Sink -holes were not observed where the depth of mining was greater than $50 \mathrm{~m}$. significant thickness of surface deposits such as soils, clays, sands and gravels tended to inhibit the formation of sink-holes.

- Xiaojun Zhu et al, (2015) studied the simulation analysis of strata movement characteristics of backfill-strip mining in China and indicated that the subsidence value of overburden strata above the backfilling working face is small because filling body can effectively support the overburden strata. The subsidence value of overburden strata above the caving working face is large. The surface maximum subsidence value for traditional caving method is $2086 \mathrm{~mm}$, the subsidence rate is 0.77 . The surface maximum subsidence value for backfilling mining is $445 \mathrm{~mm}$, the subsidence rate is 0.16 .

The subsidence parameters in different mining ways [7] is given in the following table.

TABLE II. SUBSIDENCE PARAMETERS

\begin{tabular}{|l|l|l|l|}
\hline $\begin{array}{c}\text { Subsidence } \\
\text { Parameters }\end{array}$ & $\begin{array}{c}\text { Backfill } \\
\text { mining }\end{array}$ & $\begin{array}{c}\text { Strip } \\
\text { mining }\end{array}$ & $\begin{array}{c}\text { Caving } \\
\text { mining }\end{array}$ \\
\hline $\begin{array}{l}\text { Maximum } \\
\text { subsidence } \\
\text { value/mm }\end{array}$ & 445 & 488 & 2086 \\
\hline Subsidence rate & 0.16 & 0.18 & 0.77 \\
\hline
\end{tabular}

Looking into the above literature, it was then confirmed that the estimated subsidence parameters for Ukwa Mine is reasonably accepted as the method of mining is horizontal cut and fill with post filling of sand hydraulically. Roof support like cable bolt and roof bolt has been deployed. Based on the surface topography and correlation with the underground mining operations monitoring sites has been selected for 3-D monitoring of subsidence parameters.

\section{Subsidence Monitoring AT UKWA Mine}

Subsidence monitoring stations has been installed at forest area of eastern and western side of the lease area. Established subsidence monitoring stations for 3-D recording of $\mathrm{X}, \mathrm{Y}, \mathrm{Z}$ coordinates Easting/Departure $\mathrm{X}$ (deg), (Northing/Latitude Y (deg), and Elevation/RL Z (m) ) is continuously monitored from last 3 years. Location plan of measuring stations for subsidence at Ukwa Mine in Forest Land is shown in Fig.8. Latitude, longitude and reduce 
levels are being measured by total station and monitored quarterly in dip and strike direction of the property in forest area. Subsidence pillars are installed at dip direction and in strike direction for real time monitoring of the subsidence movement. Moreover, the distance between the consecutive points of subsidence stations is also monitored quarterly and it has been vetted annually by the research/ academic institutions of the country for their suggestions and recommendations.

\section{A. Subsidence Monitoring Stations in Forest Land}

The monitoring stations with subsidence pillars have been properly erected on the surface land area and quarterly measurement is being done by total station and GPS to monitor the 3-D coordinates. Photograph of the measuring pillar of subsidence BP-II located in west side of the property is shown in (Fig. 9). Measurement of the subsidence by total station at Ukwa Mine is shown in (Fig.10).

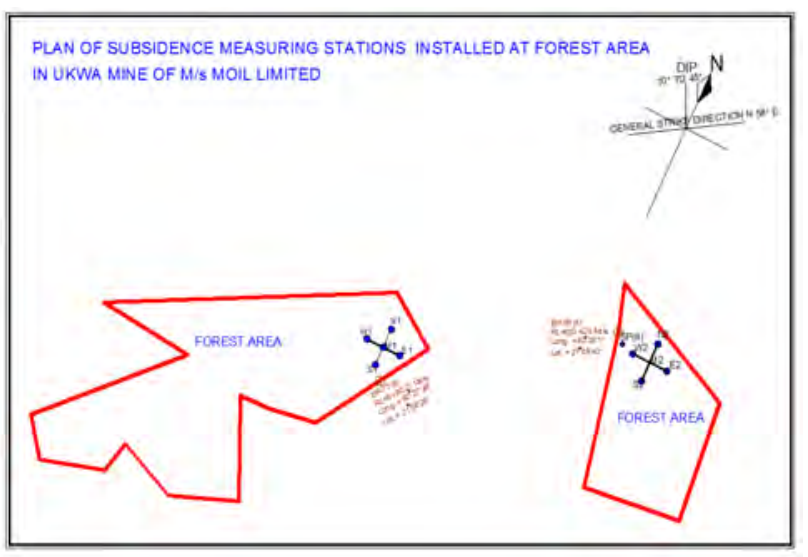

Fig. 8: Plan of monitoring stations for subsidence at Ukwa Mine in forest land

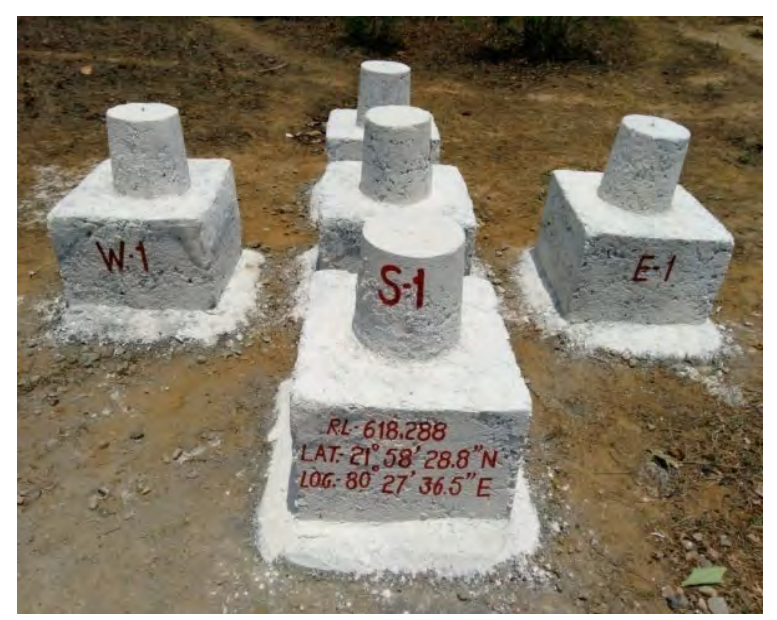

Fig. 9. Photographs of the subsidence pillars with 3-D marking - Lat, Long and RL in Forest Area of West Side at Ukwa Mine

\section{Monitoring data}

Monitoring of the data at western and eastern part of the property at Ukwa Mine from October, 2014 to March 2016 of 2 (two) referred monitoring subsidence pillars BP-77 (II) and $\mathrm{SP}-\mathrm{II}$ is given below;

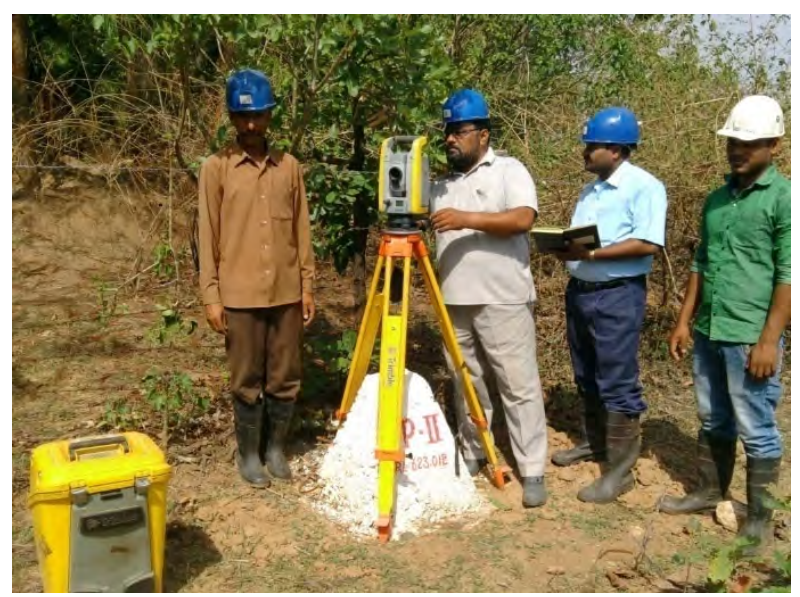

Fig. 10. Monitoring of subsidence pillars with total station

TABLE III: 3D SUBSIDENCE MONITORING

WESTERN PART OF THE PROPERTY AT BP -77 (II) QUARTER OCT 2014 TO DEC 2014

\begin{tabular}{|l|l|l|l|}
\hline Station & RL (M) & Lat (N) & Long (E) \\
\hline BP-77 (II) & 619.027 & $21^{\circ} 58^{\prime} 28.8^{\prime \prime}$ & $80^{\circ} 27^{\prime} 36^{\prime \prime}$ \\
\hline M1 & 618.247 & $21^{\circ} 58^{\prime} 28.8^{\prime \prime}$ & $80^{\circ} 27^{\prime} 36.5^{\prime \prime}$ \\
\hline N1 & 318.186 & $21^{\circ} 58^{\prime} 28.9^{\prime \prime}$ & $80^{\circ} 27^{\prime} 36.5^{\prime \prime}$ \\
\hline S1 & 618.288 & $21^{\circ} 58^{\prime} 288^{\prime \prime}$ & $80^{\circ} 27^{\prime} 36.5^{\prime \prime}$ \\
\hline E1 & 618.255 & $21^{\circ} 58^{\prime} 28.8^{\prime \prime}$ & $80^{\circ} 27^{\prime} 36.5^{\prime \prime}$ \\
\hline W1 & 618.227 & $21^{\circ} 58^{\prime} 28.8^{\prime \prime}$ & $80^{\circ} 27^{\prime} 36.5^{\prime \prime}$ \\
\hline
\end{tabular}

TABLE IV. QUARTER JANUARY 2016 TO MARCH 2016

\begin{tabular}{|l|l|l|l|}
\hline Station & RL (M) & LAT (N) & LONG (E) \\
\hline BP-77 (II) & 619.027 & $21^{\circ} 58^{\prime} 28.8^{\prime \prime}$ & $80^{\circ} 27^{\prime} 36^{\prime \prime}$ \\
\hline M1 & 618.247 & $21^{\circ} 58^{\prime} 28.8^{\prime \prime}$ & $80^{\circ} 27^{\prime} 36.5^{\prime \prime}$ \\
\hline N1 & 318.186 & $21^{\circ} 58^{\prime} 28.9^{\prime \prime}$ & $80^{\circ} 27^{\prime} 36.5^{\prime \prime}$ \\
\hline S1 & 618.288 & $21^{\circ} 58^{\prime} 28.8^{\prime \prime}$ & $80^{\circ} 27^{\prime} 36.5^{\prime \prime}$ \\
\hline E1 & 618.255 & $21^{\circ} 58^{\prime} 28.8^{\prime \prime}$ & $80^{\circ} 27^{\prime} 36.5^{\prime \prime}$ \\
\hline W1 & 618.227 & $21^{\circ} 58^{\prime} 28.8^{\prime \prime}$ & $80^{\circ} 27^{\prime} 36.5^{\prime \prime}$ \\
\hline
\end{tabular}

TABLE V. 3D SUBSIDENCE MONITORING-EASTERN PART OF THE PROPERTY AT SP - II; QUARTER OCT 2014 TO DEC 2014

\begin{tabular}{|l|l|l|l|}
\hline Station & RL & LAT (N) & LONG (E) \\
\hline BP-56 (II) & 623.429 & $21^{\circ} 58^{\prime} 40^{\prime \prime}$ & $80^{\circ} 28^{\prime} 1^{\prime \prime}$ \\
\hline SP-II & 623.012 & $21^{\circ} 58^{\prime} 40^{\prime \prime}$ & $80^{\circ} 28^{\prime} 2^{\prime \prime}$ \\
\hline M2 & 623.997 & $21^{\circ} 58^{\prime} 39.69^{\prime \prime}$ & $80^{\circ} 28^{\prime} 2.4^{\prime \prime}$ \\
\hline N2 & 623.995 & $21^{\circ} 58^{\prime} 39^{\prime \prime} 9^{\prime \prime}$ & $80^{\circ} 28^{\prime} 2.4^{\prime \prime}$ \\
\hline S2 & 623.992 & $21^{\circ} 58^{\prime} 39.69^{\prime \prime}$ & $80^{\circ} 28^{\prime} 2.4^{\prime \prime}$ \\
\hline E2 & 623.990 & $21^{\circ} 58^{\prime} 39.69^{\prime \prime}$ & $80^{\circ} 28^{\prime} 2.4^{\prime \prime}$ \\
\hline W2 & 623.895 & $21^{\circ} 58^{\prime} 39.69^{\prime \prime}$ & $80^{\circ} 28^{\prime} 2.4^{\prime \prime}$ \\
\hline
\end{tabular}


TABLE VI. QUARTER JAN 2016 TO MARCH 2016

\begin{tabular}{|l|l|l|l|}
\hline Station & RL & Lat (N) & Long (E) \\
\hline BP-56 (II) & 623.429 & $21^{\circ} 58^{\prime} 40^{\prime \prime}$ & $80^{\circ} 28^{\prime} 1^{\prime \prime}$ \\
\hline SP-II & 623.012 & $21^{\circ} 58^{\prime} 40^{\prime \prime}$ & $80^{\circ} 28^{\prime} 2^{\prime \prime}$ \\
\hline M2 & 623.997 & $21^{\circ} 58^{\prime} 39.69^{\prime \prime}$ & $80^{\circ} 28^{\prime} 2.4^{\prime \prime}$ \\
\hline N2 & 623.995 & $21^{\circ} 58^{\prime} 39.69^{\prime \prime}$ & $80^{\circ} 28^{\prime} 2.4^{\prime \prime}$ \\
\hline S2 & 623.992 & $21^{\circ} 58^{\prime} 39.69^{\prime \prime}$ & $80^{\circ} 28^{\prime} 2.4^{\prime \prime}$ \\
\hline E2 & 623.990 & $21^{\circ} 58^{\prime} 39.69^{\prime \prime}$ & $80^{\circ} 28^{\prime} 2.4^{\prime \prime}$ \\
\hline W2 & 623.895 & $21^{\circ} 58^{\prime} 39.69^{\prime \prime}$ & $80^{\circ} 28^{\prime} 2.4^{\prime \prime}$ \\
\hline
\end{tabular}

\section{CONCLUSIONS}

The maximum possible subsidence in case of underground extraction of manganese under the surface land at Ukwa mine has been examines and found safe. Considering the geotechnical properties of the mineral, host rocks and numerical modeling analysis for ground movement of the underground working with post filling by hydraulic sand stowing, the surface prediction models used in India for steep coal deposits has been used for calculation of maximum subsidence, slope of subsidence and the compressive and tensile strains. The values are worked out as $45 \mathrm{~mm}, 1.33 \mathrm{~mm} / \mathrm{m}, 0.73 \mathrm{~mm} / \mathrm{m}$ and $0.66 \mathrm{~mm} / \mathrm{m}$ respectively. The above values are found to be quite safe considering the safe limits established for various surface properties in India.

Quarterly 3-D monitoring (X,Y.Z coordinates) of the subsidence for Easting- Departure/ Longitude - $X$, Northing/Latitude - Y, and Reduce Level/Elevation - Z in dip and strike direction of the property at Ukwa mine has been carried out from Oct., 2014 to March 2016. The analysis of monitoring data shows that there is no depression and deviation in 3-D coordinates $(\mathrm{X}, \mathrm{Y}, \mathrm{Z})$ and thus it is indicated that the chances of subsidence is minimal. The quarterly monitoring data clearly suggests that no noticeable movement took place in any of the three orthogonal directions in lease area of Ukwa Mine. This is evidence enough that the subsidence at the Ukwa mine surface land area is not of any measurable significance. The primary reason for the near absent subsidence following mining is attributed to the diligent and systemic hydraulic sand filing of underground voids created. The predicted maximum tensile strain is $0.66 \mathrm{~mm} / \mathrm{m}$, which is very minimal. Moreover, since the inception of underground workings at Ukwa Mine no subsidence has been observed till date.

\section{REFERENCES}

[1] CMRI Final Report on Ukwa Mine, Project No. GC/H/4/96, Dhanbad, (April 1999).

[2] CMRI Report, $2^{\text {nd }}$ Interim Report on Geotechnical properties and classification parameters of Munsar, Beldongri, Chikla and Gumgaon Mine. 4 p, 2001.

[3] Saxena N.C and Singh B,"Subsidence research in India, Int. symposium on Land Subsidence", CMRI, Dhanbad, Dec 11-15, p 88$102,1989$.
[4] Sheorey P R, Loui J.P., Singh K B and Singh S K, "Ground subsidence observations and a modified influence functions method for complete subsidence prediction", Int. Jour. of Rock Mech. and Mining Science, 37, pp 801-818, 2000.

[5] Singh U K, Report on Design of Mechanized over hand cut and fill method of stoping for manganese ore body of Ukwa mine, ISM, Dhanbad, May 2014.

[6] Whittaker B.N and Reddish, Elsevier - Subsidence- Occurrence, Prediction and Control, Development in Geo-technical Engineering, $56,1989$.

[7] Xiaojun Zhu, Huangli Guo, Zhi Qian, Qi Fang and Tao Chen, "Simulation analysis of strata movement characteristics of backfillstrip mining", Journal of Mines, Metals \& Fuels (Nov-Dec, 2015), India - pp 411-418, 2015.

[8] Rao I S and Deb D, IIT, "Kgp Prediction of Subsidence for the Metal Mine using numerical modelling techniques", Mining Engineers Journal, Sept, 2016, pp 22-27 (Sept, 2016). 